\title{
Decoupling Economic Growth from Fossil Fuels
}

\author{
Peter Newman \\ Curtin University, Perth, Australia \\ Email: p.newman@curtin.edu.au
}

How to cite this paper: Newman, P. (2017) Decoupling Economic Growth from Fossil Fuels. Modern Economy, 8, 791-805. https://doi.org/10.4236/me.2017.86055

Received: January 29, 2017

Accepted: June 3, 2017

Published: June 6, 2017

Copyright $\odot 2017$ by author and Scientific Research Publishing Inc. This work is licensed under the Creative Commons Attribution International License (CC BY 4.0).

http://creativecommons.org/licenses/by/4.0/

\begin{abstract}
The decoupling of fossil fuels from economic growth has not been imaginable for most of the industrial era but is now underway. The data for this are presented for the world and for typical nations. The mechanisms behind this are outlined and suggest that climate change goals to end poverty and to achieve the phasing out of fossil fuels are achievable if the trends are mainstreamed.
\end{abstract}

\section{Keywords}

Cities, Decoupling, Decarbonisation, Disruption, Forecasting

\section{Introduction}

In 2015/16 the world's governments committed to two core sets of goals for the future: the Sustainable Development Goals (SDG's) and the Paris Agreement on Climate Change action which essentially aims to phase out fossil fuels by 2100 and $80 \%$ by 2050 . Inherent in the achievement of the SDG's is the need for economic growth, especially in the dominant SDG1 "End poverty in all its forms everywhere". Yet in the past this has led to increases in fossil fuels and hence greenhouse emissions. Are the SDG's therefore inherently in conflict with the need for climate change action? Or can the world achieve decoupling of economic growth from fossil fuels and greenhouse gases?

For some these two sets of goals are incompatible as GDP and fossil fuels, hence greenhouse gases or GHG, have been totally coupled for over a hundred years so climate change action can only be achieved by degrowth [1]. For others, especially the UNEP and IPCC, who are more positive about sustainable development achieving economic and environmental goals together, the agenda of decoupling GHG and GDP is critical [2] [3].

\section{Methods}

The data for wealth and economic growth are from the World Bank [4] and GHG are from the International Energy Agency [5]. GDP and GNI are very sim- 
ilar measurements of economic growth and GNI was chosen due to greater availability. They are standardized to a date back in the 1990's where it is possible to show how growth rates begin to separate out and indicate the level of decoupling.

\section{Evidence}

In 2016 the International Energy Agency announced that the world had changed. For the first time in hundreds of years the world was producing less greenhouse emissions than the year before without this being caused by an economic crisis [5]. In 2015 the amount of GHG emitted to the world's atmosphere decreased by around $0.5 \%$ whilst economic growth continued at more than $3 \%$. A few scientists had predicted this but mostly the fossil fuel lobby had been in complete denial over its possibility [6].

Figure 1 shows that for the first time the industrial world was producing wealth without this meaning more fossil fuels and more emissions. Despite its huge implications for a world that has faced down the global climate issue for decades without much good news, the world's media were virtually silent. Perhaps this was because the EIA (from the US Government Energy Information Administration) were more sanguine predicting a continued growth in GHG of $1 \%$, though their data were only up to 2012 and in reality, they did not consider the possibility of major changes often picked up by groups such as Carbon Tracker [7] [8]. Indeed, Carbon Tracker has shown that the new trends in GHG are following the kind of projections made by the IPCC's carbon emissions targets much more closely than any other conservative projections.

The decoupling of greenhouse gas emissions (GHG) from wealth (usually measured as GDP or GNI, gross national income) has been a UN agenda for

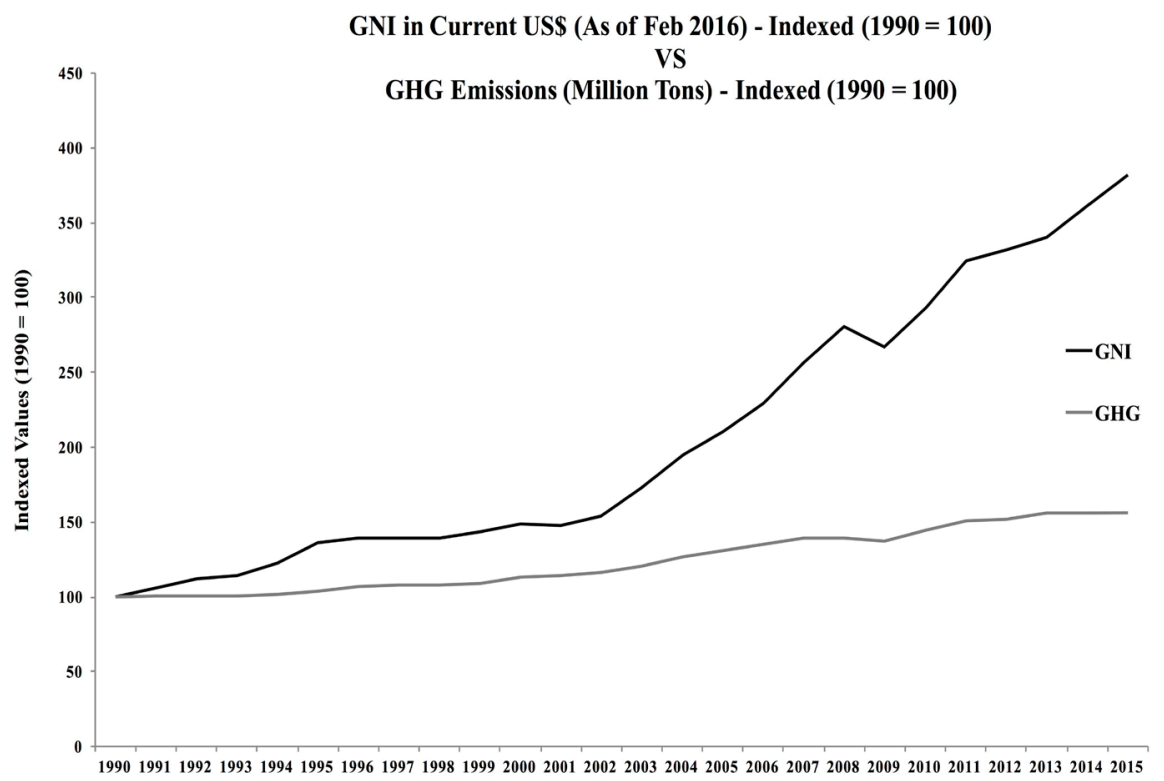

Figure 1. Growth in wealth with plateau and decline in greenhouse emissions. Source: [4] [5]. 
several decades [2] [3]. The first signs of decoupling began in the 1990's as Figure 1 indicates and their trajectories have been separating out quite rapidly for most of the $21^{\text {st }}$ century. For many commentators and scientists, such as the IPCC, this relative decoupling was not significant enough for a world needing less total GHG until the actual decline in global emissions began. Now we appear to have reached a point where this can be seen in a peak in global greenhouse emissions. We now have absolute decoupling for the first time.

\subsection{Understanding the Causes}

The simplest explanation for decoupling is to see the mathematical relationship between GHG and GDP as:

$$
\text { GHG/GDP = GHG/Energy } \times \text { Energy } / \text { GDP }
$$

GHG/Energy is called the carbon intensity and Energy/GDP is called the energy intensity. GHG/GDP will lower as the national carbon intensity decreases from greater use of renewables and natural gas; energy intensity will decrease as energy efficiency increases. Thus the increased use of renewables and the increased energy efficiency result in a relative decoupling of GHG from wealth. This relative decoupling was set as the basis for many national goals rather than seeking actual absolute reductions in GHG, especially if the countries were growing fast economically (like China and India) and were expected to have low but rapidly expanding GHG. This was seen by coal companies as the reason why coal consumption would continue to rise [9] [10].

This paper will show some of the rationale for why this is happening faster than expected but in particular that it is being driven by the world's cities. Because cities are rapidly growing we can expect decoupling will continue to rapidly phase out the world's dependence on fossil fuels and continue its goals in ending poverty.

Figure 1 shows that Gross National Income (a way of measuring global wealth) has decoupled from greenhouse gas emissions. The notion of decoupling is based on the same idea as the economic theory of Environmental Kuznets Curves (EKC) which shows that as wealth grows people begin to choose environmental quality increasingly once their basic needs have been met. Decoupling is however happening earlier than expected in many parts of the world and indicates that there is more to this process than just simply getting wealthier. Perhaps one very key finding by a $2012 \mathrm{ADB}$ report [11] is that the EKC was related to how quickly urbanization is happening as it is in cities that the phenomenon is most easily observed.

In Figure 2 we have begun to breakdown the GHG into its main components by looking at consumption of coal and oil which are the largest causes of GHG.

The spurt in global coal growth in recent times was mostly due to China but as can be seen in Figure 3 that era is over and China declined in its coal consumption in 2015 for the first time. Oil has also begun to plateau in China. The driving forces behind this will be outlined later but it is important to see that the 


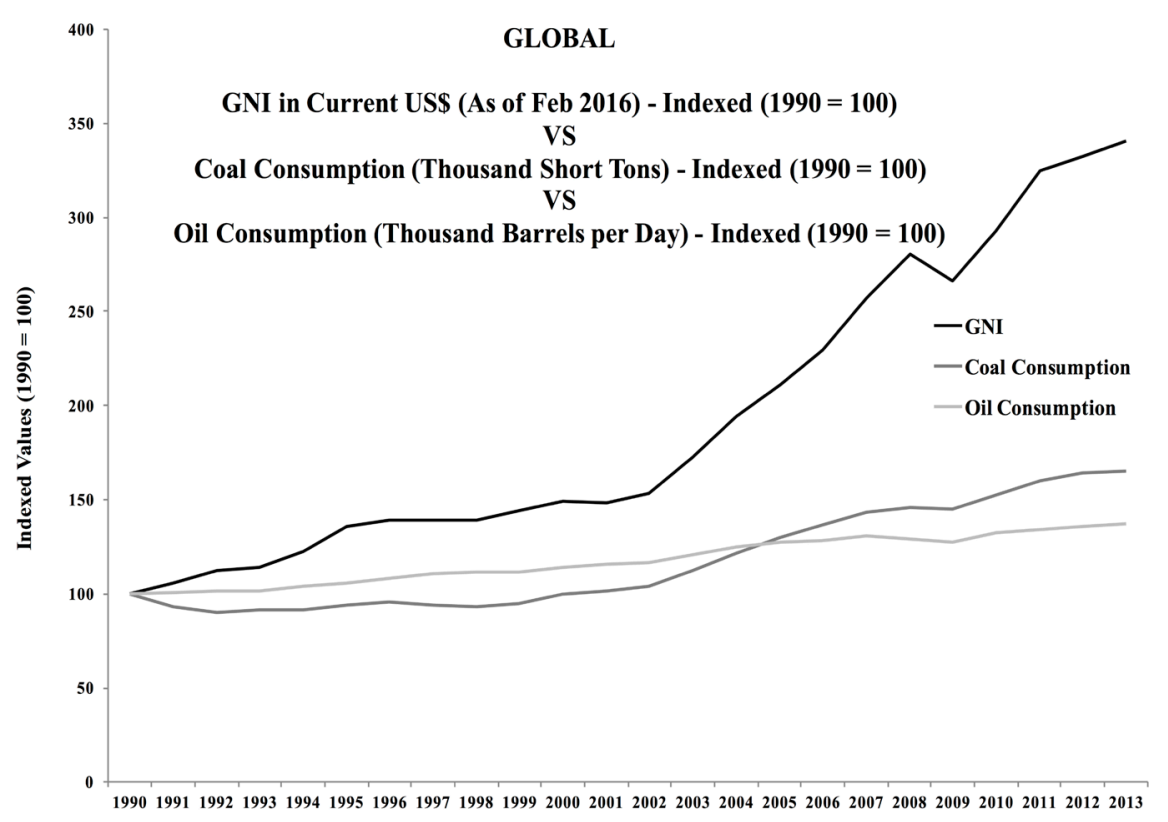

Figure 2. Global growth in wealth with consumption of coal and oil. Source: [4] [5].

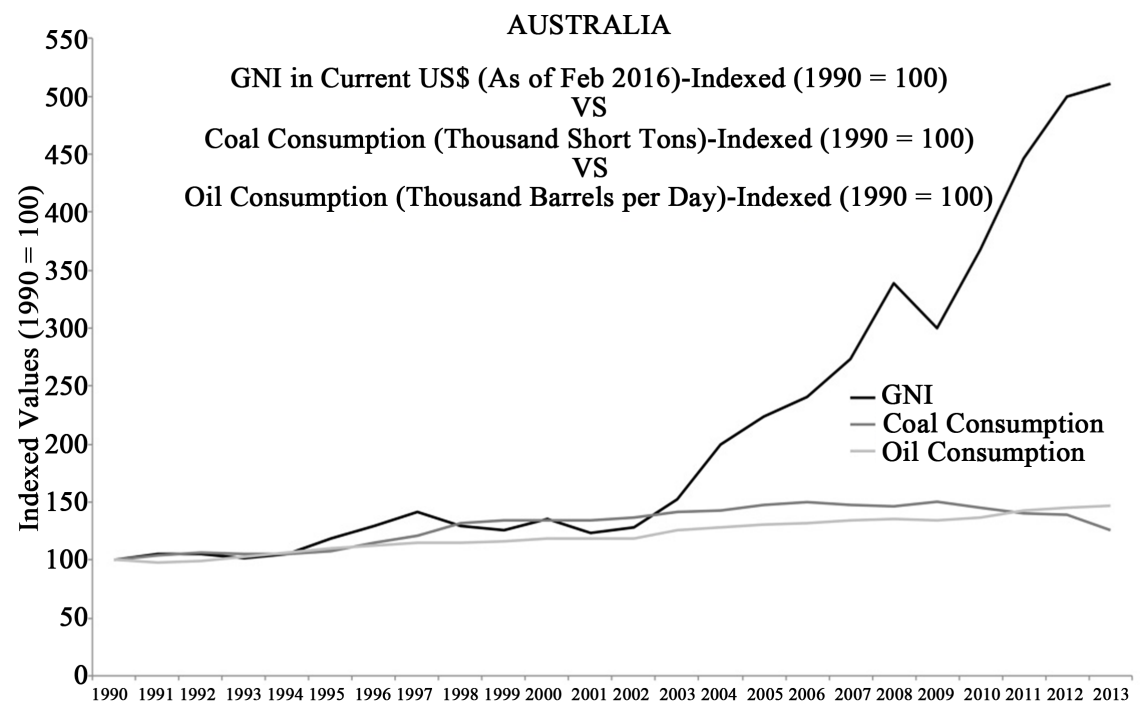

Figure 3. Decoupling wealth from coal and oil in Australia. Source: [4] [5].

growth in China's economy is no longer dependent on growth in fossil fuels; they are phasing out and yet China is becoming wealthier.

Indeed it is important to see that the reduction in GHG has occurred after an extraordinary 15 years of economic growth that took China out of its extreme poverty. The global Millenium Goals that were agreed to by the world's nations in 2000 for the period up to 2015 focused on how development could halve extreme poverty-defined as being less than $\$ 1.25$ per day. Across the developing world people living in extreme poverty declined from $47 \%$ to $22 \%$ between 1990 and 2010-achieving the Millenium Goal 5 years ahead of time [12]. This was mostly due to rapid declines in extreme poverty in China and India with some improvement in Africa. This process has taken around 1 billion people out of 
extreme poverty in a 15 year period.

It is also important to see that the rapid decline in poverty has mostly occurred within cities and that the extremely rapid urbanization in China (and now in India and Africa) is what fuels this dramatic change. It also clear that there was not as much concern in this rapid urbanization in the emerging world's cities for achieving fossil fuel and GHG reductions; these cities were and are focusing on ending poverty. But the new trend in China which decoupling is now underway provides great hope that the process will now spread to the whole emerging world. China is probably going to show the way to decouple rapidly as they invested $\$ 90$ billion in renewables in 2015 (more than 60\% of their investment in energy) so much of their continuing growth will be based around solar and wind rather than the fossil fuel-based economic growth of the past 15 years. The data on developed nations below show that decoupling can be anticipated in all elements of economic growth as GHG decoupling has set in.

The big question for the world is whether this process of absolute decoupling is likely to continue in places like China and India and Africa as they develop. In Figures 3-6 we have presented the data on decoupling for Australia, China, Denmark and the United States to show that the extent of absolute decoupling is now considerable and this indicates that the global decoupling process is likely to continue.

The largest decoupling is in Denmark, where the absolute decoupling began back in 1994 and has continued since, with coal and oil in significant decline without impacting on their overall growth in wealth. The US and Australia are following this pattern though not as spectacularly as Denmark. Most European nations have similar trajectories to Denmark.

The EIA data in Figure 7 on China and the US, which stops in 2012 and so is not as clear in recent times about absolute decoupling, is certainly showing the sources of the decoupling. The reduction in the ratio of GHG over GDP in-

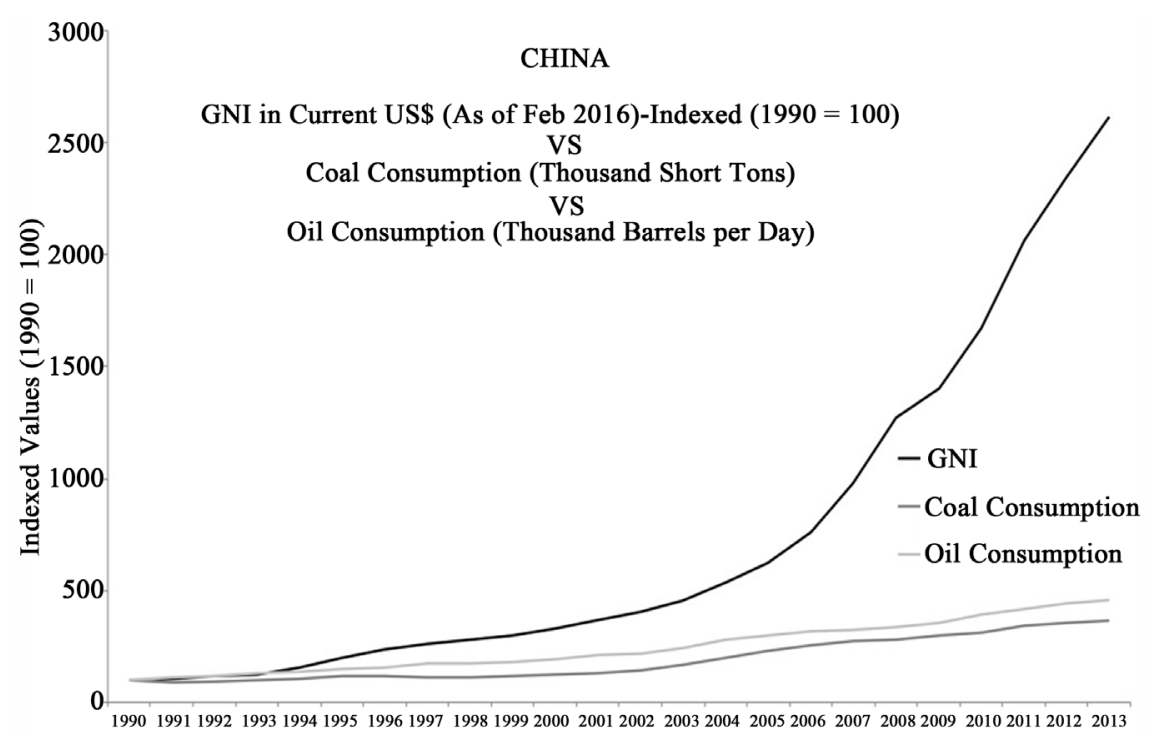

Figure 4. Decoupling wealth from coal and oil in China. Source: [4] [5]. 


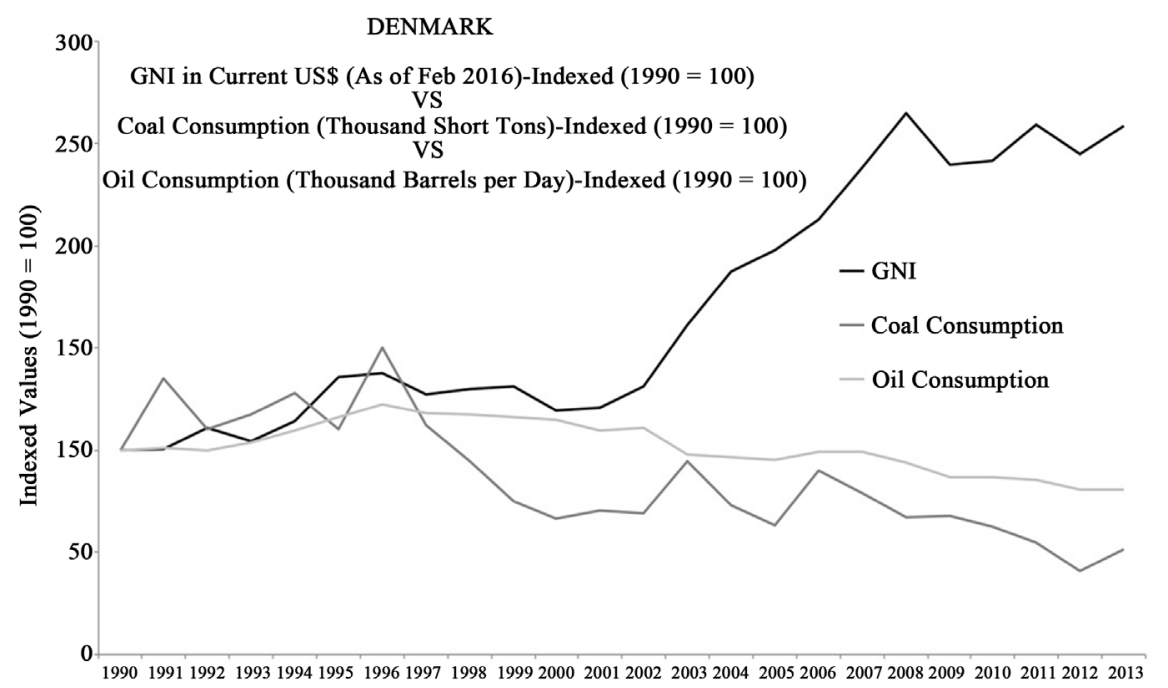

Figure 5. Decoupling wealth from coal and oil in Denmark. Source: [4] [5].

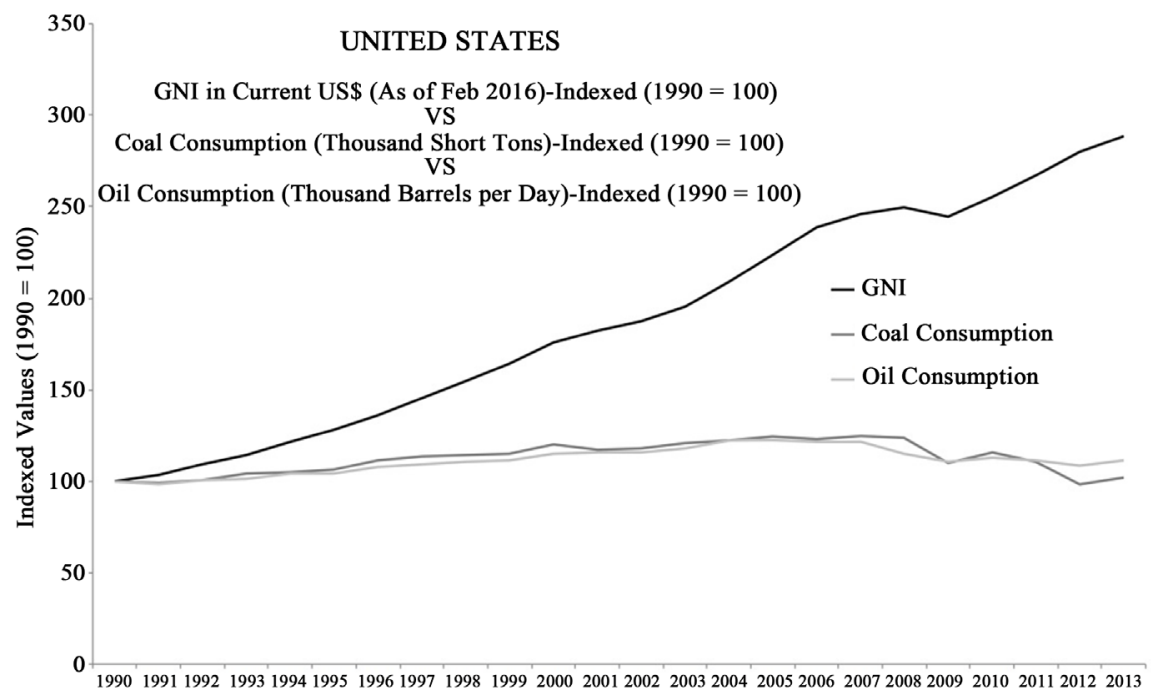

Figure 6. Decoupling wealth from coal and oil in the United States. Source: [4] [5].
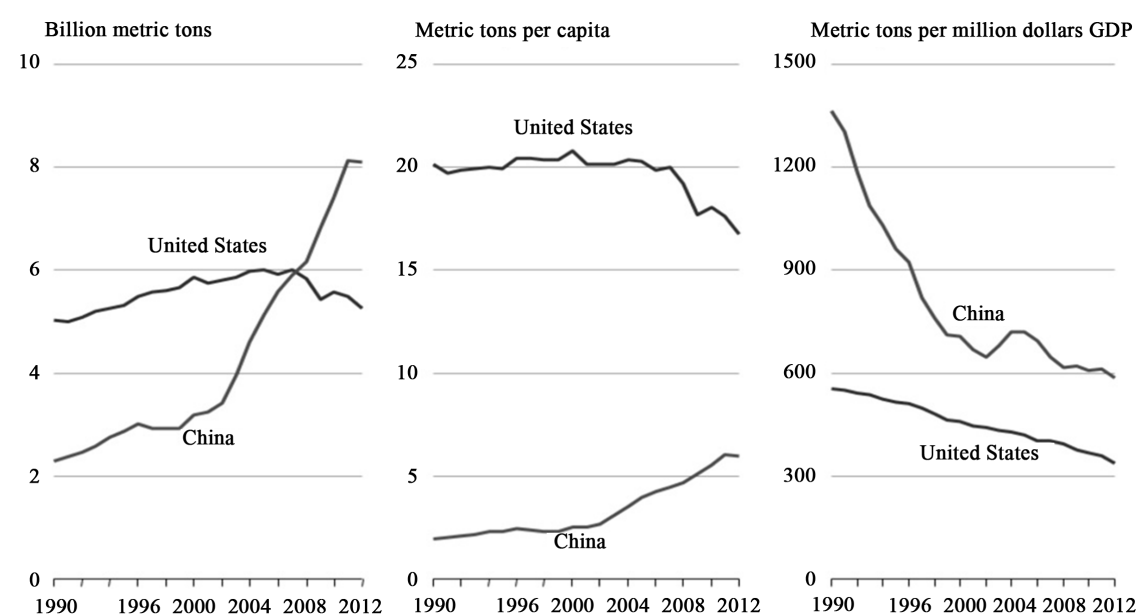

Figure 7. Decoupling GHG from wealth in China and the US showing how rapidly China began reducing GHG per unit of GDP. Source: [7]. 
cludes both energy efficiency and growth in renewables leading to a decoupling of GHG and GDP of around $60 \%$ over 22 years in China and nearly $50 \%$ in the US. Similar data is available on India, the fourth largest emitter of GHG, and they have made very significant commitments to solar and to electric rail as well as energy efficiency that could lead to their absolute decoupling well before EKC theory would have predicted [13].

Although many would not want to say that the battle is over, there is no doubt that the era of fossil fuel dependence is ending. It obviously needs to keep going and gain exponential decline momentum. Our book is written to help with that momentum through the powerful forces of change that are potentially available in our cities.

\subsection{Causes of Decoupling}

The three primary sources of change are government, business and the community [14]. Each of these play a part in any change and will be briefly outlined here before showing how the power of cities to bring these together is what is really driving the world to decouple from fossil fuels.

\subsubsection{Government}

The Paris agreement in December 2015 (COP21) was an historic accord signed by 196 nations. It was significantly easier for the nations of the world to sign than in Copenhagen in 2009 (COP15) as the world could now see that the changes being required on them were already underway without causing a decline in wealth generation, as outlined above in Figure 1 and in national data.

Nevertheless it was a significant achievement and a lot of lobbying and government activity was required to demonstrate that it was now possible to commit more heavily to the journey of removing fossil fuel-based economies $100 \%$ by 2100. The follow-up commitments began in New York in April 2016 with a signing by 175 nations to ensure that climate change is "well below" the 2 degrees' limit accepted by the world's scientists. Each country must now deliver the ratification from their parliaments and begin the adoption of annual goals that are meant to be ratcheted up whenever the country feels able to do so.

The role of government in providing regulations and infrastructure to enable higher energy efficiency and low carbon electricity, fuels, appliances, buildings and vehicles has been a driver of change over the past 30 years. This process is usually one of being a small step ahead and pushing the system to produce a better low carbon outcome without too much cost or change. However it is possible, that disruptive innovations will begin to take over markets much quicker than governments have allowed for. In our view the emergence of solar and battery storage is likely to rapidly displace coal and the reduction of car dependence and electrification of transport is likely to rapidly displace oil. This process will depend on whether business and the community can see the changes emerging and accept that new fossil fuel-free goals are achievable in their cities and towns and how they can use the opportunity to ride this new economic wave rather than try to prevent the change. 


\subsubsection{Business}

There is a lot of evidence that the next area of growth for business is the green economy and that there are large groups of businesses partially or totally funding green innovation, products and services as the basis of their future [15].

The most significant driver in the $21^{\text {st }}$ century leading to the removal of coal (and gas) for electricity production has been investment in renewables. As shown in Figure 8 below there was a point around 2004 when investment in renewables by the world's bankers and financiers outstripped fossil fuel-based power investment. In the most recent data from Bloomberg New Energy Finance the investment ratio is now 2:1 in favour of renewables.

Business has often been seen to have very short term goals of a year or so in terms of their strategic plans for market gains. But investors from the financial community look to see how they will make profits right through the lending period which is usually 20 years. When governments are debating the world's scientists about how quickly they can remove fossil fuels from the market place, then it is easy to see why they would not want to invest in potential stranded assets like coal-fired power stations when other options that governments and scientists want to see, are available.

In the US in the past 5 to 8 years the phasing out of coal was made easier by the availability of natural gas. At the same time dramatic growth in solar and wind power was underway and now it is possible to see how the natural gas limits are being reached as renewables becomes the fuel of choice [17]. The combination of these two forces led to the collapse of coal consumption in the US and decline and fall of the largest coal company Peabody with many stranded assets.

In Australia a similar process has been underway with gas as the preferred option over coal but in the past 5 years the dramatic growth in rooftop solar has created a significant market that was not considered likely for decades. 1.5 million homes purchased roof top solar in 5 years without any real subsidies like feed-in tariffs and in Perth this reached 25\% of households. The 550 MW produced is the largest power station in Western Australia and has led to the Minis-

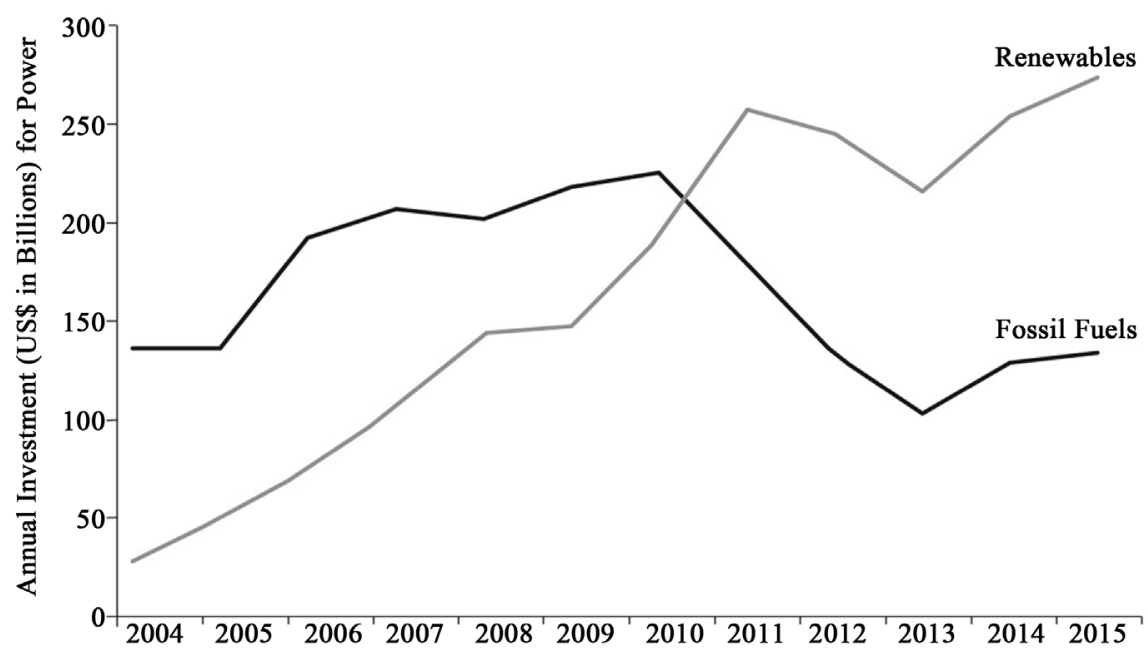

Figure 8. Investment in coal and gas for power vs renewables, 2004-2015.Source: [16]. 
ter Energy saying growth will inevitably reach $70 \%$ of households by 2020 and the utilities will never again need to purchase a coal or gas-fired power station [18].

The implications for the cities and towns in Western Australia for how they manage a potentially carbon-free power future in the next decade are a journey they were not prepared for. Fossil fuel-based power stations are now likely to be stranded assets and the key questions are about how battery storage can make this transition seamless for business and households and how it can enable the electricity grid to be maintained as a way of equitably distributing solar electricity. This is likely to be different in different parts of the city as well as in different types of settlements in rural and remote locations, as will be discussed later.

\subsubsection{Community}

The reasons why Perth grew so rapidly in adoption of solar include factors like easy access to Chinese mass produced PV cells (and now batteries) and the high price of electricity, but mostly it was driven by the community. In the 8 years from 2008 there was a significant economic boom in Western Australia when the rest of the world was frantically adapting to the GFC. For a period Perth became the wealthiest city in the world and the new money was flooding into many household bank accounts. Many chose to put it into a rooftop solar system because of their interest in long term sustainability (over $80 \%$ of the community want to see action on climate change) as well as having an investment that would pay for itself in 5 years.

Community values can easily be underestimated when facing the future and the need to address complex matters like climate change. The majority of this rooftop solar has gone into the outer suburbs which in Australia are generally less wealthy though they often have bigger homes with bigger roofs and bigger power bills [19]. The inner suburbs are much higher socio-economically and have higher green intentions but in reality it was the outer suburbs who have made the majority of the investment in solar. It indicates that the mechanisms for decoupling economic growth and fossil fuels will vary between cities and within cities [20].

\subsection{What about Oil?}

The reduction in consumption of oil is another example of how cities have begun to drive the change to remove fossil fuels at a faster rate than many anticipated. It also is a combination of government, business and the community.

The collapse in oil price as well as the collapse in coal price appears to be due to demand issues as well as supply issues. Demand for coal will continue to drop as renewables takes over; especially as battery storage becomes cheap. Demand for oil is expected to decline as vehicle fleets are electrified; however it has already gone down despite there being only a few percent of electric vehicles. The reason why this has happened appears to be a city issue: for the past 150 years cities have been moving out as they have followed first trains and trams then automobiles, but now they are coming back in [21]. 
Our work on cities has shown that there is an exponential relationship between urban density and car use/fuel use as in Figure 9.

If cities have begun to increase in density rather than decrease then they will drop down the steep curve quite quickly creating exponential decline in car use. This is what we are now seeing in all the world's developed cities and the phenomenon is being called 'peak car' as car use per capita has peaked and is in decline. Indeed it is very similar to the decoupling phenomenon described above. Many cities are now seeing that their economic growth is dependent on them reducing their car use. Hence cities like Washington DC and Portland, Oregon have demonstrated that their wealth is decoupling from car use (Figure 10).

It should be no surprise that this strong decoupling is associated with cities that have invested in good urban rail systems in recent decades. The decoupling is closely associated with this as our data also shows that urban traffic is slowing in all the world's cities and urban rail is now able to outcompete cars as they can go around, over or under the traffic [21].

Governments play a big part in generating this transition as they are needed to help plan, though not necessarily finance, such large scale infrastructure. However business and community are also critical as they are responding to a new economic process associated with the knowledge economy. Many businesses that are part of the new innovation economy are locating in city centres where they can have creative face-to-face contact with people from various backgrounds and professions [22] [23]. These new jobs are generally for the young Millenials and also older wealthier professionals. As a result they are the backbone of the social movement that has rediscovered inner and central city living. The market demand for dense urbanism that is not car dependent has therefore grown dramatically in the $21^{\text {st }}$ century city.

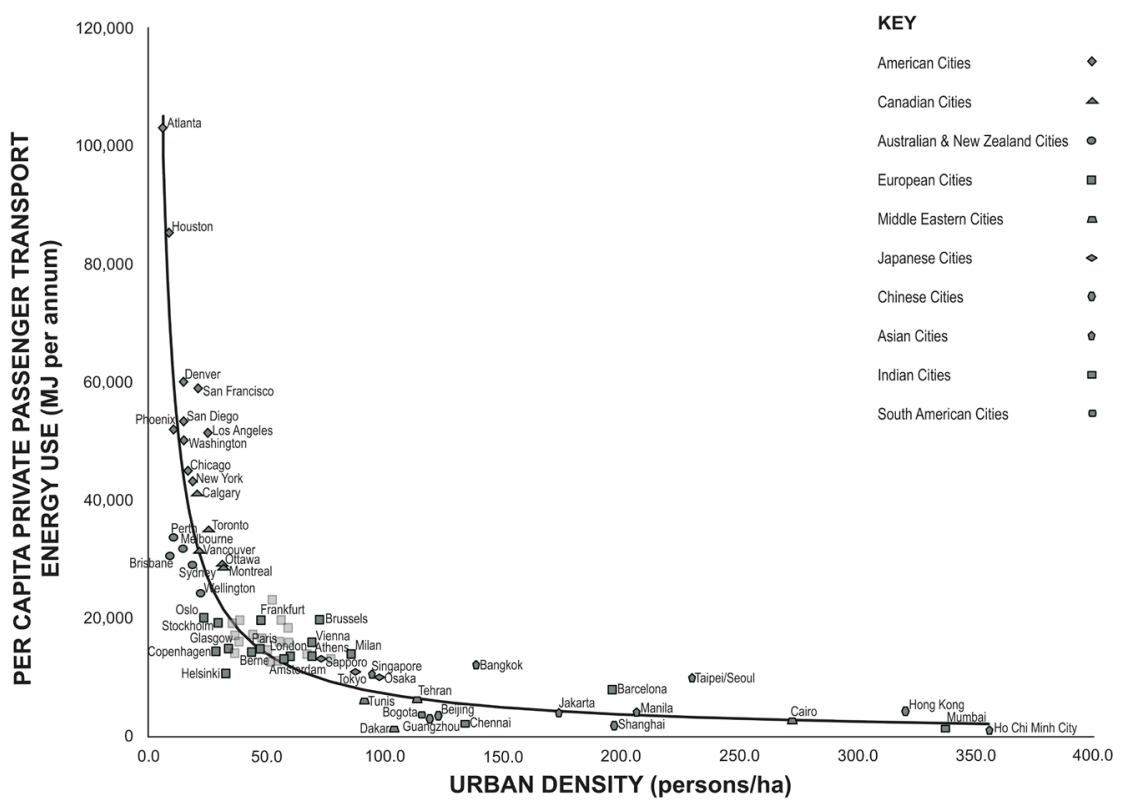

Figure 9. The exponential relationship between urban density and transport fuel use. Source: [21]. 

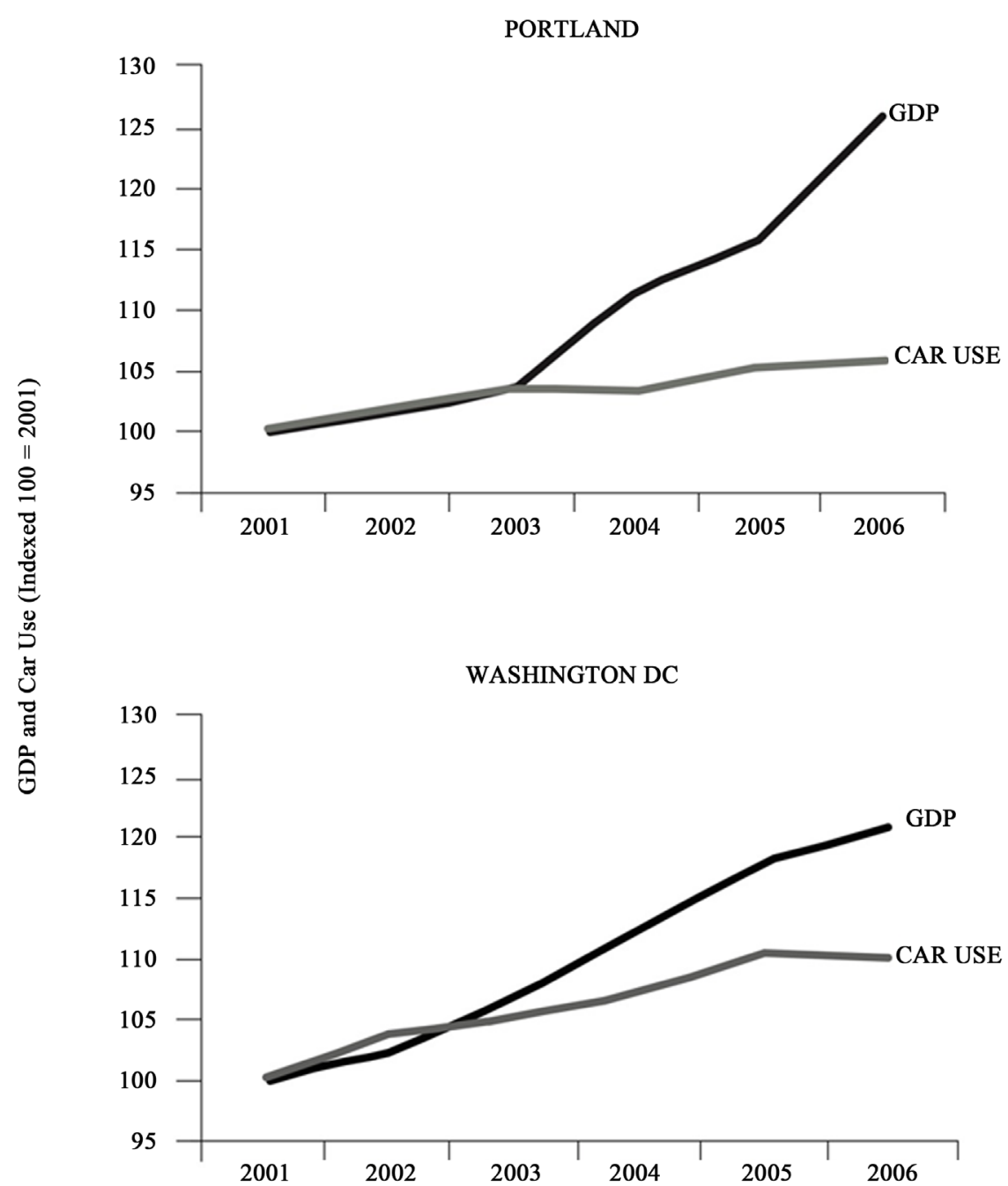

Figure 10. The exponential relationship between urban density and transport fuel use. Source: [21].

In more recent work the same phenomenon of peak car has been found in Shanghai and Beijing which are now carrying 8 and 9 million passengers a day on their new Metro systems enabling a significant reduction in the relative use of cars [24]. The rapid change into decoupling growth in wealth from growth in car use is happening in emerging cities because they have the urban fabric that is not suited to large scale growth in car use. The building of 81 electric urban rail systems in Chinese cities and 52 in Indian cities is indicative of how the switch away from oil is happening before many expected.

\subsection{The Future}

A range of fossil fuel demand forecasts and the forecast just for renewables are set out in Figure 11. The nine organizations they used include the main fossil fuel companies and the main government-based forecasting bodies of the IEA and the EIA. The average growth from 2015 to 2050 is $580 \mathrm{EJ}$ to $850 \mathrm{EJ}$ with the oil companies suggesting well above these forecasts. The average for renewables 

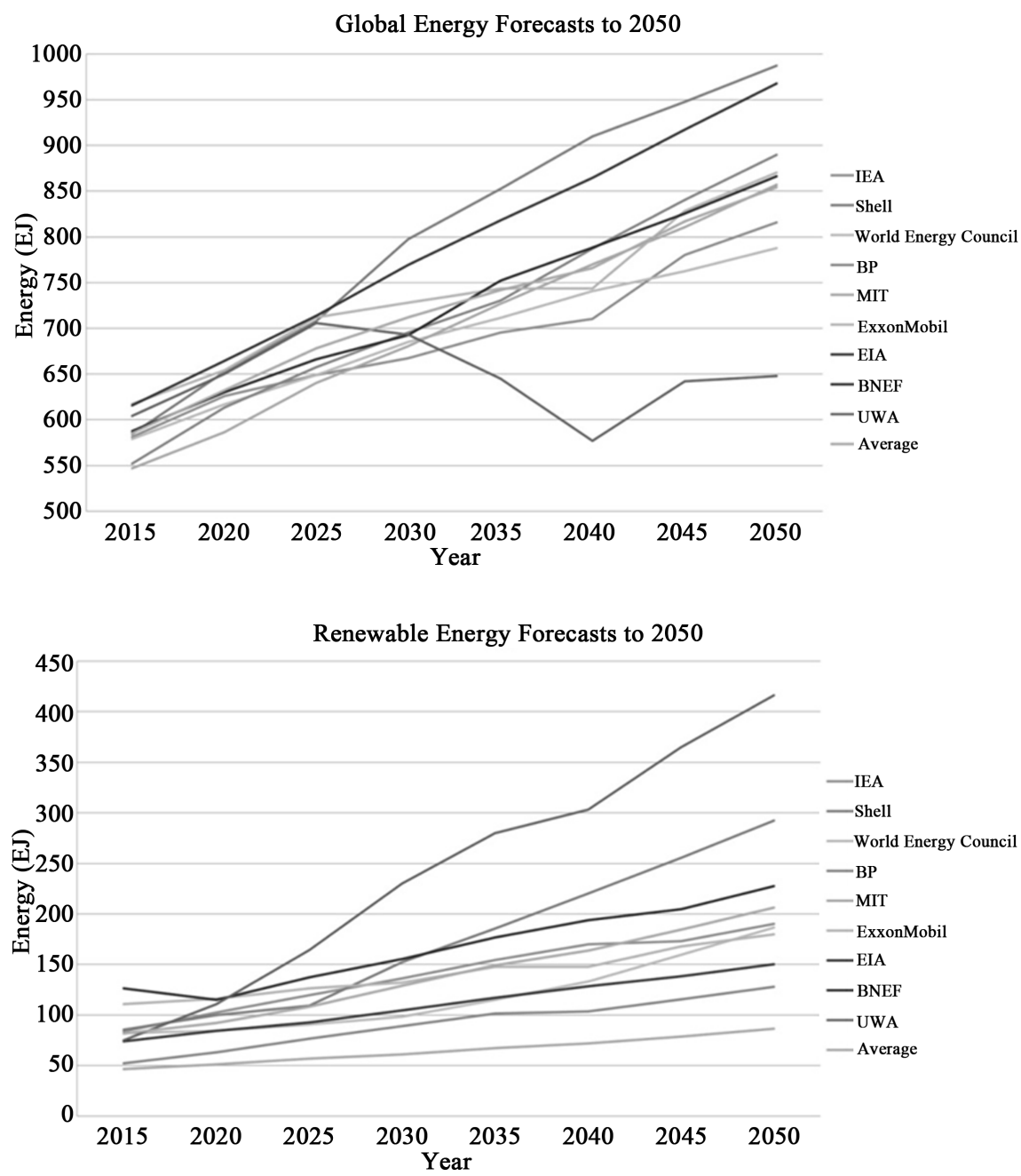

Figure 11. Global energy and renewable energy forecasts to 2050 from various sources. Source: [18].

goes from $80 \mathrm{EJ}$ to $200 \mathrm{EJ}$ with the fossil fuel companies suggesting much less than this.

What this suggests is that based on historical trends global energy demand is forecast simply to grow in line with global population growth and growth in GDP. Owing to this, fossil fuel companies predict that due to the continued forecasted rise of energy consumption, their products will meet the majority of this demand with a small though growing proportion of renewables. This is business as usual. However, this paper has shown that decoupling of fossil fuel energy from GDP has become firmly established and is being driven by cities from across the world. What if the trends are setting in to be significantly faster than most of these forecasts dare to suggest?

What could happen if we took seriously the kind of disruptive innovations in our cities that are likely to lead to rapid decline in fossil fuels and rapid growth in renewables? In order to separate out the components of GHG growth we have used the Kaye simplification (based on the old Paul Ehrlich simplification of Impact being a combination population, resource consumption per capita and 
technology efficiency per unit of resource consumption):

$$
\begin{aligned}
\mathrm{GHG}= & \text { carbon intensity per unit of energy (GHG/Energy) } \\
& \times \text { energy intensity per unit of wealth }(\text { Energy/GDP) } \\
& \times \text { wealth per capita }(\text { GDP/populatio }) \times \text { population }
\end{aligned}
$$

The carbon intensity of energy is going down globally and will increase rapidly as renewables increases its proportion. The decoupling of energy from wealth has been increasing with a 35\% decoupling between 1990 and 2015 and from the above diagrams this will grow even more rapidly as the two separate out. Wealth per capita is likely to continue its gradual growth and population growth is predicted to continue but slow. The interactions between all these factors are complex for example urban population growth will help propel the economic processes that enable solar adoption and urban regeneration as well as being a factor in creating more GHG until these processes enable the phase out.

The scenario considered most feasible will be something like the IPCC goal of $80 \%$ less GHG by 2050 as in Figure 12 .

\section{Conclusion}

The end of fossil fuel dependence is hard to imagine but it is getting easier because the trends show it is underway. This paper has shown the kind of exponential growth in renewables and decline in fossil fuels that we have just started to see could in fact decouple economic growth from fossil fuels much more rapidly than most have forecasted. The continuation of these trends will require a combination of different forms of solar-based power, different forms of electric transport and different forms of urban fabric. Most of this will be in cities. Government, business and the community will drive it in different ways in different parts of cities.

\section{Predictions-After the Peak}

GDP

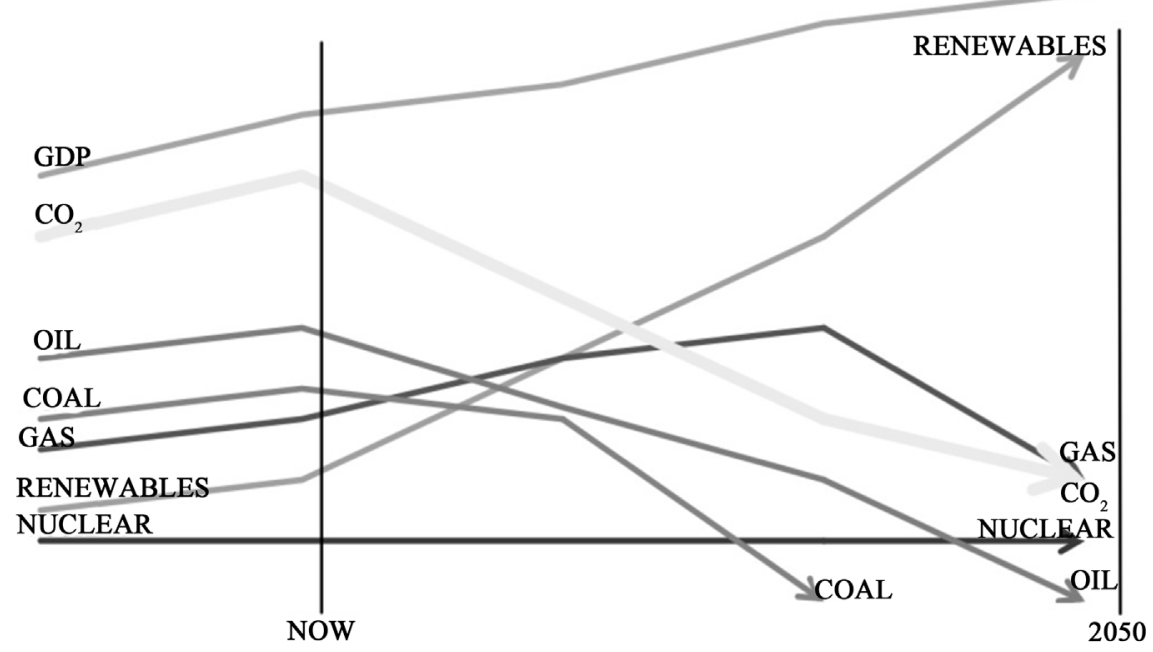

Figure 12. Global energy and renewable energy forecasts to 2050 from various sources. Source: [21]. 


\section{Acknowledgements}

The author would like to acknowledge the assistance provided by his research assistant Philip Webster in getting this paper ready for publishing.

\section{References}

[1] Jackson, T. (2009) Prosperity without Growth: Economics for a Finite Planet. Earthscan, London.

[2] United Nations Environment Programme (UNEP) (2011) Towards a Green Economy: Pathways to Sustainable Development and Poverty Eradication. Report, United Nations Environment Programme, Nairobi.

https://web.unep.org/greeneconomy/sites/unep.org.greeneconomy/files/field/image Igreen economyreport final dec2011.pdf

[3] United Nations Environment Programme (UNEP) (2014) Decoupling 2, Technologies Opportunities and Policy Options: A Report of the Working Group on Decoupling to the International Resource Panel. Report, United Nations Environment Programme, Nairobi.

http://www.unep.org/resourcepanel/portals/24102/pdfs/irp decoupling 2 report.p df

[4] World Bank Group (WBG) (2013) Towards a Sustainable Energy Future for All: Directions for the World Bank Groups Energy Sector. Report, World Bank Group, Washington DC.

http://www-wds.worldbank.org/external/default/WDSContentServer/WDSP/IB/201 3/07/17/000456286 20130717103746/Rendered/PDF/795970SST0SecM00box37738 0B00PUBLIC0.pdf

[5] International Energy Agency (IEA) (2015) World Energy Outlook: Special Report on Energy and Climate Change. Report, International Energy Agency, Paris. https://www.iea.org/publications/freepublications/publication/WEO2015SpecialRep ortonEnergyandClimateChange.pdf

[6] Weiss, K.R. (2015) Global Greenhouse-gas Emissions Set to Fall in 2015. Nature News.

[7] U.S. Energy Information Administration (EIA) (2016) International Energy Outlook 2016. Report, Energy Information Administration, Washington DC. https://www.eia.gov/outlooks/ieo/pdf/0484(2016).pdf

[8] Schuwerk, R. and Sussams, L. (2016) No Rhyme or Reason: Unreasonable Projections in a World Confronting Climate Change. Report, Carbon Tracker Initiative (CTI), London.

https://www.carbontracker.org/wp-content/uploads/2016/07/EIAdesigned-10_page s.pdf

[9] Sussams, L. and Leaton, J. (2017) Expect the Unexpected: The Disruptive Power of Low-Carbon Technology. Report, Carbon Tracker Initiative, London.

http://www.carbontracker.org/wp-Content/uploads/2017/02/Expect-the-Unexpecte d CTI Imperial.pdf

[10] Dowling, P. and Gray, M. (2016) End of the Load for Coal and Gas? Challenging Power and Technology Assumptions. Report, Carbon Tracker Initiative, London. http://www.carbontrack-Er.org/wp-content/uploads/2016/09/LCOE-report-v7.pdf

[11] Asian Development Bank (ADB). (2012) Part 1-Special Chapter: Green Urbanization in Asia. In: ADB, Ed., Key Indicators for Asia and the Pacific 2012, Report, Asian Development Bank, Manila.

https://www.adb.org/sites/default/files/publication/29940/ki2012.pdf 
[12] United Nations (UN). (2015) The Millennium Development Goals Report 2015. Report, United Nations, New York. http://www.un.org/milleniumgoals/2015_MDG_Report/pdf/MDG\%202015\%20rev \%20(July\%201).pdf

[13] King, E. (2016) India to meet climate goals earlier than promised, says outgoing climate chief. The Guardian.

https://www.theguardian.com/environment/2016/jul/13/india-to-meet-climate-goal s-earlier-than-promised-says-outgoing-climate-chief

[14] Newman, P. and Kenworthy, J. (1997) Sustainability and Cities. Island Press, Wash ington DC.

[15] Newton, P. and Newman, P. (2015) Critical Connections: The Role of the Built Environment sector in Delivering Green Cities and the Green Economy. Sustainability, 7, 9417-9443. https://doi.org/10.3390/su7079417

[16] Bloomberg New Energy Finance (BNEF) (2015) New Energy Outlook 2015: Long-Term Projections of the Global Energy Sector. Report, Bloomberg New Energy Finance, New York.

[17] Green, J. and Newman, P. (2016) Disruptive Innovation, Stranded Assets and Forecasting: The Rise and Rise of Renewable Energy. Journal of Sustainable Finance and Investment, 7, 1-19.

[18] Green, J. and Newman, P. (2017) Citizen Utilities. Energy Policy, In Press. https://doi.org/10.1016/j.enpol.2017.02.004

[19] Newton, P. and Newman, P. (2013) The Geography of Solar PV and a New Low Carbon Urban Transition Theory. Sustainability, 5, 2537-2556. https://doi.org/10.3390/su5062537

[20] Newman, P., Kosonen, L. and Kenworthy, J. (2016) Theory of Urban Fabrics: Planning the Walking, Transit and Automobile Cities for Reduced Automobile Dependence, Town Planning Review, 87, 429-458. https://doi.org/10.3828/tpr.2016.28

[21] Newman, P. and Kenworthy, J. (2015) The End of Automobile Dependence: How Cities are Moving Beyond Car-Based Planning. Island Press, Washington DC. https://doi.org/10.5822/978-1-61091-613-4

[22] Glaeser, E. (2011) The Triumph of the City, How our Greatest Invention Makes Us Richer, Smarter, Greener, Healthier and Happier. Penguin Press, London.

[23] Florida, R. (2010) The Great Reset: How New Ways of Living and Working Drive Post Crash Prosperity. Harper Collins, New York.

[24] Gao, Y., Newman, P. and Kenworthy, J. (2017) Are Beijing and Shanghai Reaching Peak Car? Applying Urban Fabric Theory Chinese Cities. Urban Studies, In Press. 
Submit or recommend next manuscript to SCIRP and we will provide best service for you:

Accepting pre-submission inquiries through Email, Facebook, LinkedIn, Twitter, etc. A wide selection of journals (inclusive of 9 subjects, more than 200 journals)

Providing 24-hour high-quality service

User-friendly online submission system

Fair and swift peer-review system

Efficient typesetting and proofreading procedure

Display of the result of downloads and visits, as well as the number of cited articles Maximum dissemination of your research work

Submit your manuscript at: http://papersubmission.scirp.org/

Or contact me@scirp.org 